\title{
Polyamidoamine dendrimer impairs mitochondrial oxidation in brain tissue
}

\author{
Gabriella Nyitrai ${ }^{1 *}$, László Héja', István Jablonkai ${ }^{1}$, Ildikó Pál ${ }^{1}$, Júlia Visy² and Julianna Kardos ${ }^{1}$
}

\begin{abstract}
Background: The potential nanocarrier polyamidoamine (PAMAM) generation $5\left(\mathrm{G} 5-\mathrm{NH}_{2}\right)$ dendrimer has been shown to evoke lasting neuronal depolarization and cell death in a concentration-dependent manner. In this study we explored the early progression of $\mathrm{G} 5-\mathrm{NH}_{2}$ action in brain tissue on neuronal and astroglial cells.

Results: In order to describe early mechanisms of $\mathrm{G} 5-\mathrm{NH}_{2}$ dendrimer action in brain tissue we assessed $\mathrm{G}_{5}-\mathrm{NH}_{2}$ trafficking, free intracellular $\mathrm{Ca}^{2+}$ and mitochondrial membrane potential $\left(\Psi_{\text {MITO }}\right)$ changes in the rat hippocampal slice by microfluorimetry. With the help of fluorescent dye conjugated $\mathrm{G} 5-\mathrm{NH}_{2}$, we observed predominant appearance of the dendrimer in the plasma membrane of pyramidal neurons and glial cells within 30 min. Under this condition, $\mathrm{G} 5-\mathrm{NH}_{2}$ evoked robust intracellular $\mathrm{Ca}^{2+}$ enhancements and $\Psi_{\text {MITO }}$ depolarization both in pyramidal neurons and astroglial cells. Intracellular $\mathrm{Ca}^{2+}$ enhancements clearly preceded $\Psi_{\text {MITO }}$ depolarization in astroglial cells. Comparing activation dynamics, neurons and glia showed prevalence of lasting and transient $\psi_{\text {MITO }}$ depolarization, respectively. Transient as opposed to lasting $\Psi_{\text {MITO }}$ changes to short-term $\mathrm{G} 5-\mathrm{NH}_{2}$ application suggested better survival of astroglia, as observed in the CA3 stratum radiatum area. We also showed that direct effect of $\mathrm{G} 5-\mathrm{NH}_{2}$ on astroglial $\Psi_{\text {MITO }}$ was significantly enhanced by neuron-astroglia interaction, subsequent to $\mathrm{G} 5-\mathrm{NH}_{2}$ evoked neuronal activation.
\end{abstract}

Conclusion: These findings indicate that the interaction of the PAMAM dendrimer with the plasma membrane leads to robust activation of neurons and astroglial cells, leading to mitochondrial depolarization. Distinguishable dynamics of mitochondrial depolarization in neurons and astroglia suggest that the enhanced mitochondrial depolarization followed by impaired oxidative metabolism of neurons may be the primary basis of neurotoxicity.

Keywords: Nanotoxicity, PAMAM dendrimer, Brain tissue, Calcium enhancement, Mitochondrial depolarization

\section{Background}

Polyamidoamine (PAMAM) dendrimers are hyperbranched "protein-like" polymers with well-defined globular structure and monodispersed, nanoscopic particle size. PAMAM dendrimers have been reported to be able to cross the blood-brain barrier and are used as nanoparticle delivery systems to carry DNA, drugs or imaging agents to the brain [1-3]. Despite its wide application in the brain, only general toxic effects of dendrimers have been studied [4-6], much less information is available about their effects on neural cells.

\footnotetext{
* Correspondence: nyitrai.gabriella@ttk.mta.hu

'Department of Functional Pharmacology, Institute of Molecular Pharmacology, Research Centre for Natural Sciences, Hungarian Academy of Science, Budapest, Hungary

Full list of author information is available at the end of the article
}

In our recent study we showed that application of polycationic PAMAM generation $5\left(\mathrm{G} 5-\mathrm{NH}_{2}\right)$ dendrimers induced severe depolarization and subsequent inactivation of hippocampal pyramidal neurons in brain slices. Additionally, cell death after $\mathrm{G} 5-\mathrm{NH}_{2}$ application was also observed in a concentration dependent manner [7]. In the present study we characterize the early intracellular processes sequential to $\mathrm{G} 5-\mathrm{NH}_{2}$ induced neuronal depolarization and explore the effect of dendrimer application on astroglial cells.

In addition to their role in maintaining neuronal function, astroglial cells have been disclosed as active contributors in signal processing $[8,9]$. Furthermore, we also reported on astroglial signaling independent of neuronal activity in acute brain slices isolated from the rat nucleus accumbens [10]. In general, neurons are more susceptible to oxidative injury than astrocytes, due to their

\section{() Biomed Central}


limited antioxidant capacity [11]. During oxidative stress astrocytes support neuronal function by providing antioxidant protection $[11,12]$. Therefore damage resulting in astrocyte dysfunction leads to increased neuronal death [11]. Oxidative damage in neural tissue can be detected by the loss of mitochondrial membrane potential ( $\left.\Psi_{\text {MITO }}\right)$, a marker of mitochondrial dysfunction $[11,13]$ that is sensitively coupled to neuronal and astroglial activation and survival $[11,14,15]$. $\Psi_{\text {MITO }}$ is also coupled to intracellular $\mathrm{Ca}^{2+}$ regulation $[11,13,14,16]$. Changes in intracellular $\mathrm{Ca}^{2+}$ level indicate activation of neuronal $[17,18]$ or astroglial cells $[10,19,20]$.

Membrane-dendrimer interactions have been studied extensively, supporting the view that cationic dendrimers interact with biological membranes $[4,21,22]$. Interactions are often followed by cellular internalization of cationic PAMAM dendrimers [23].

Here we report that application of $\mathrm{G} 5-\mathrm{NH}_{2}$ dendrimer induces robust intracellular $\mathrm{Ca}^{2+}$ signals in both neuronal and astroglial cells followed by severe $\Psi_{\text {MITO }}$ depolarization indicating the disruption of neuronal oxidative metabolism.

\section{Results and discussion}

\section{Plasma membrane appearance of fluorescently labeled}

G5- $\mathrm{NH}_{2}$ in neuronal and astroglial cells

To determine the localization of $\mathrm{G} 5-\mathrm{NH}_{2}$ in the rat hippocampal slices we covalently conjugated the fluorescent
Rhodamine Green dye to $\mathrm{G} 5-\mathrm{NH}_{2}$ and studied the localization of the fluorescently labeled dendrimer with confocal microscopy after 30 minutes of incubation. We found robust plasma membrane appearance of $0.1 \mathrm{mg} /$

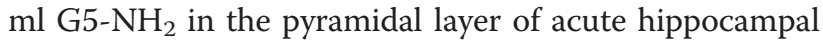
slices (Figure $1 \mathrm{~A}, \mathrm{n}=3$ slices). Fluorescent $\mathrm{G} 5-\mathrm{NH}_{2}$ appeared predominantly on the cell membrane of pyramidal neurons, although weak internalization of the dendrimer was also observed (Figure 1A). On astroglial cells a patchy membrane distribution of the green fluorescent $\mathrm{G} 5-\mathrm{NH}_{2}$ was detected as colocalization with the astroglia-specific red fluorescent marker sulforhodamine-101, SR101, Figure $1 \mathrm{~B}, \mathrm{n}=5$ slices), suggesting direct interaction between the astroglial cell membrane and the dendrimer (Figure 1B).

\section{Intracellular $\mathrm{Ca}^{2+}$ responses of astroglial cells and neurons}

To investigate whether interaction of $\mathrm{G} 5-\mathrm{NH}_{2}$ with the plasma membrane of neurons and astroglia affects their function, we monitored intracellular $\mathrm{Ca}^{2+}$ signals that sensitively reflect the activity of both cell types. Astroglial $\mathrm{Ca}^{2+}$ signals were monitored in the astroglia-rich stratum radiatum area in the hippocampal CA3 region after bulk loading of the rat hippocampal slice with the $\mathrm{Ca}^{2+}$ sensitive fluorescent dye Fluo-4 [10,24] (Figure 2A-C, $\mathrm{n}=7$ slices). Astroglial localization of the dye was confirmed by colocalization with the astroglia-specific SR101 marker
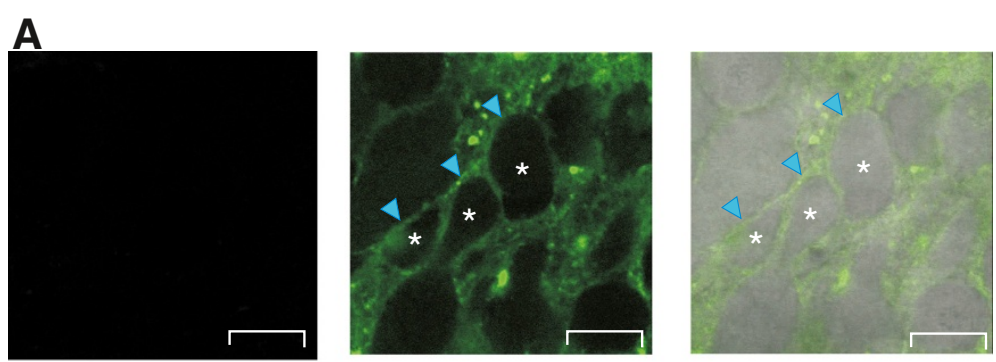

B
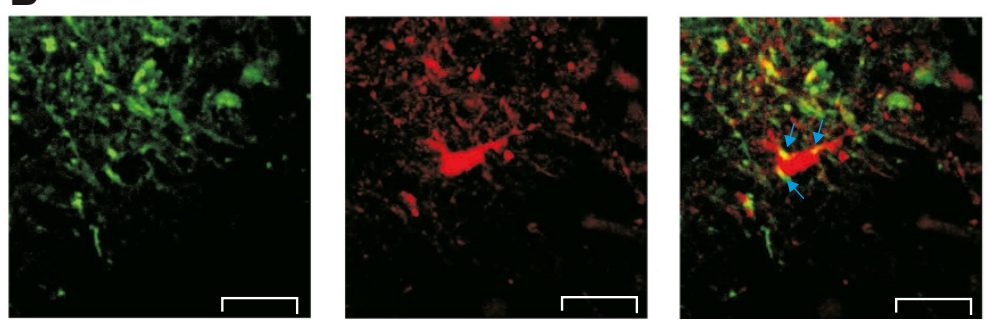

Figure 1 Plasma membrane appearance of Rhodamine Green conjugated $\mathrm{G} 5-\mathrm{NH}_{2}$ in the rat hippocampal slice after 30 min incubation with $0.1 \mathrm{mg} / \mathrm{ml}$ conjugated dendrimer. A: No fluorescence signal was detected from slices without dendrimer application (Left, control) Green fluorescent contour of pyramidal neurons in the hippocampal CA3 area indicates the occurrence of dendrimer mainly in the plasma membrane (asterisks - center of the cells, arrowheads point to the plasma membrane). B: Appearance of the green fluorescent dendrimer (Left) and the astroglia specific red fluorescent marker SR101 (Middle) in the stratum radiatum area next to the CA3 pyramidal cells. Yellow spots in the superimposed image (Right) indicate localization of the dendrimer to the plasma membrane of the soma and processes of an astroglial cell (arrows). Scale bars: $20 \mu \mathrm{m}$. 

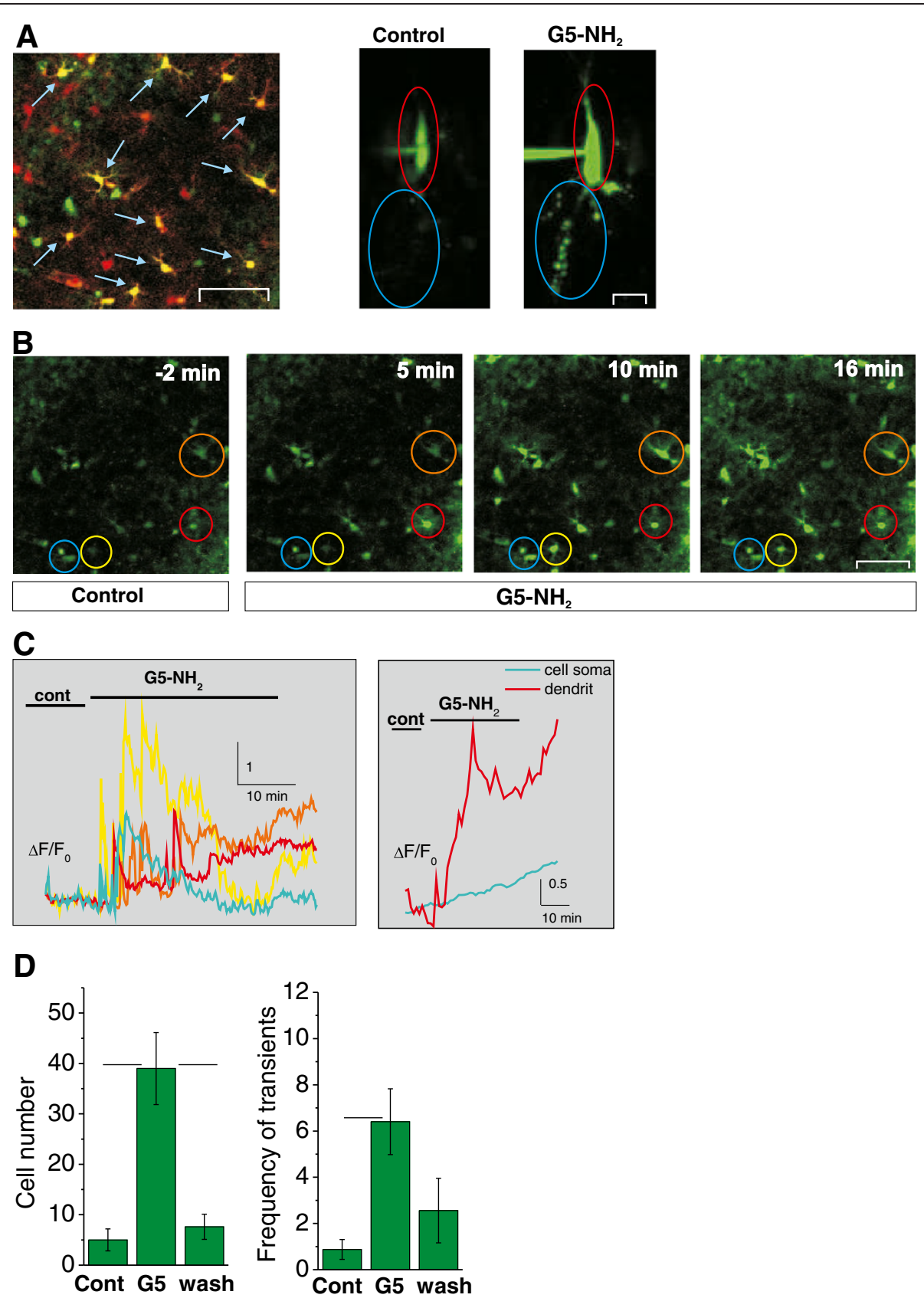

Figure $2 \mathrm{G} 5-\mathrm{NH}_{2}(0.1 \mathrm{mg} / \mathrm{ml}, 30 \mathrm{~min})$ induces intracellular $\mathrm{Ca}^{2+}$ enhancements in astroglial and neuronal cells as monitored with the fluorescent $\mathrm{Ca}^{2+}$ indicator Fluo-4. A: Left: Co-localization (yellow cells pointed by blue arrows) of astroglial cells stained with the astrogliaspecific marker SR101 (red) with the Ca ${ }^{2+}$ indicator Fluo-4 (green). Scale bar: $100 \mu \mathrm{m}$. Right: Representative images of a CA3 pyramidal neuron filled with the membrane impermeable $\mathrm{Ca}^{2+}$ indicator MagFluo4 (green) before and after $\mathrm{G} 5-\mathrm{NH}_{2}$ application. Scale bar: $50 \mu \mathrm{m}$. Red and blue ovals indicate somatic and dendritic regions of the cell, respectively. B: Representative serial images showing $\mathrm{Ca}^{2+}$ enhancements in the circled astroglial cells in the stratum radiatum of the rat hippocampal slice. Scale bar: 50 um. C: Fluorescence-time plots of the astroglial cells circled in B (Left) and the neuron shown in A (Right). D: Statistical evaluation of $\mathrm{G} 5-\mathrm{NH}_{2}$ effects on astroglial $\mathrm{Ca}^{2+}$ enhancements: the number of cells showing $\mathrm{Ca}^{2+}$ enhancements (Left) and the average number of transients in 1 min (frequency) (Right). Horizontal bars represent significant differences at $p<0.05$ level.

(Figure 2A, Left). Morphologically identified neurons in the CA3 pyramidal layer were directly filled with Fluo-4 from a patch pipette in order to visualize fine dendritic processes in addition to the cell body (Figure 2A, Right, $\mathrm{n}=2$ cells).
Application of $\mathrm{G} 5-\mathrm{NH}_{2}$ evoked $\mathrm{Ca}^{2+}$ enhancements in hippocampal astroglial cells (Figure 2B-D) suggesting increased astroglial activity. $\mathrm{Ca}^{2+}$ enhancements started almost immediately after G5- $\mathrm{NH}_{2}$ application (Figure 2C). 
To quantify the effect of $\mathrm{G} 5-\mathrm{NH}_{2}$ on the astroglial $\mathrm{Ca}^{2+}$ dynamics we determined the average number of responding cells per slice and the average frequency of $\mathrm{Ca}^{2+}$ transients (calculated from the intervals measured between subsequent peaks). Both parameters increased significantly during the 30 minute application period (Figure 2D). Number of responding cells and frequency of transients fell back to the control level during the washout period (Figure 2D) indicating reversible effect of G5- $\mathrm{NH}_{2}$ on astrocytes. In some cells, however, intracellular $\mathrm{Ca}^{2+}$ level remained slightly elevated (Figure $2 \mathrm{C}$, Left, red and orange lines). In contrast, intracellular $\mathrm{Ca}^{2+}$ enhancements in pyramidal neurons were characterized by quickly developing, lasting increase in dendritic processes and almost linear increase of intrasomal $\mathrm{Ca}^{2+}$

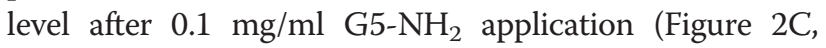
Right).

\section{Distinguishable $\Psi_{\text {MІто depolarization in neurons and }}$ astroglial cells}

The observed transient or lasting enhancements of intracellular $\mathrm{Ca}^{2+}$ level after dendrimer application may result in impaired oxidative metabolism through $\mathrm{Ca}^{2+}$ influx-induced depolarization of $\Psi_{\text {MITO }}[13,14,16]$. Mitochondrial cell death pathways have been suggested to contribute to the cytotoxic character of cationic PAMAM dendrimers in human lung cells [25]. In the brain, the neuronal activity and the mitochondrial function are highly correlated [15]. In addition, neuronal function and survival are very sensitive to mitochondrial dysfunction which can be monitored by measurement of the mitochondrial membrane potential $[13,14,26]$. To further explore this issue, we studied $\Psi_{\text {MITO }}$ changes in astroglia and neurons using the $\Psi_{\text {MITO }}$ sensitive dye rhodamine-123 [14].

Application of G5- $\mathrm{NH}_{2}(0.1 \mathrm{mg} / \mathrm{ml}, 30 \mathrm{~min})$ significantly increased the fluorescence of the $\Psi_{\text {MITO sensitive }}$ dye rhodamine-123 in both pyramidal neurons and astroglia (Figure 3A-C, astroglial cells: $\mathrm{n}=6$ slices, neurons: $\mathrm{n}=4$ slices), indicating $\Psi_{\text {MITO }}$ depolarization and impaired oxidative metabolism in both cell types. The dynamics of neuronal and astroglial response, however, showed distinctive features. Similarly to the $\mathrm{Ca}^{2+}$ responses, $\Psi_{\text {MITO }}$ increase was found to be transient in most astroglial cells (Figure $3 \mathrm{C}$ and D) Responses were considered to be transient if the fluorescence intensity returned to $\pm 20 \%$ of the baseline value within the application of $\mathrm{G} 5-\mathrm{NH}_{2}$. In contrast to astroglia, $\Psi_{\text {MITO }}$ remained elevated in the majority of neurons until the end of the experiment (Figure $3 \mathrm{C}$ and $\mathrm{D}$, lasting response), suggesting irreversible $\Psi_{\text {MITO }}$ depolarization. In addition, the duration of the response was shorter (Figure 3D). Since astroglia is morphologically similar to interneurons, we completed colocalization experiments to identify astroglial cells. The observed colocalization of the astroglia specific fluorescent dye SR101 with $\Psi_{\text {MITO }}$ depolarization monitored by the red fluorescent rhodamine-123 confirmed that, indeed, astroglial cells were probed (c.f. yellow color in the merged image Figure 3A).

To quantitatively compare the onset dynamics of $\mathrm{Ca}^{2+}$ enhancements and $\Psi_{\text {MITO }}$ depolarization we determined the temporal distribution of $\mathrm{Ca}^{2+}$ transients $\left(1783 \mathrm{Ca}^{2+}\right.$ transients were identified in 303 cells in 6 slices) and $\Psi_{\text {MITO }}$ responses (122 $\Psi_{\text {MITO }}$ peaks were measured in 144 cells in 7 slices) in all responding astroglialcells after G5- $\mathrm{NH}_{2}$ application (Figure 4). The appearance of intracellular $\mathrm{Ca}^{2+}$ transients was immediate and remarkably preceded $\Psi_{\text {міто }}$ depolarization (Figure 4 ) despite of the fact that the average number of responding astroglial cells per slice showing $\mathrm{Ca}^{2+}$ enhancements and $\Psi_{\text {MITO }}$ depolarization was not significantly different $(39 \pm 7$ vs. $24 \pm 5$, respectively; $\mathrm{p}=0.117$, one-way Anova). These data suggest a causal link between the two processes. It is to note that dynamics of intracellular $\mathrm{Ca}^{2+}$ transients and $\Psi_{\text {MITO }}$ depolarization in pyramidal neurons has been shown to be coupled during seizure-like events [14].

\section{PAMAM dendrimer evokes astroglial $\Psi_{\text {MIтO }}$ depolarization directly and via neuron-astroglia interaction}

Since neuronal activation results in the release of major excitatory and inhibitory neurotransmitters Glu and $\gamma$-aminobutyric acid (GABA), respectively, and glutamatergic activation can lead to $\Psi_{\text {MITO }}$ changes $[13,14])$, we explored whether neuronal activation modifies astroglial responses. To examine whether $\mathrm{G} 5-\mathrm{NH}_{2}$ directly affects astroglial mitochondrial function or it is the consequence of the preceding neuronal depolarization, we measured G5$\mathrm{NH}_{2}$ evoked $\Psi_{\text {MITO }}$ depolarization in the presence of the following inhibitors: blocker of voltage-gated $\mathrm{Na}^{+}$ channels tetrodotoxin (TTX, $1 \mu \mathrm{M}$ ), antagonists of Glu receptors (N-methyl-D-aspartate type: DL-2amino-5-phosphonopentanoic acid APV, $100 \mu \mathrm{M}$; AMPA/ kainate type: 6-cyano-7-nitroquinoxaline-2,3-dion CNQX, $10 \mu \mathrm{M})$ and the $\mathrm{GABA}_{\mathrm{A}}$ receptor antagonist picrotoxin $(100 \mu \mathrm{M})$. In the presence of the antagonists, the number of astrocytes showing $\Psi_{\text {MITO }}$ depolarization did not change, while the number of responding neurons significantly decreased (Figure 5A, astroglia $n=7$ slices, neurons $n=3$ slices). However, the blockade of neuronal activity decreased both the duration of the astroglial response (10.2 \pm $0.7 \min v s .7 .8 \pm 0.8 \mathrm{~min} ; \mathrm{p}=0.049$, one-way Anova) and the percentage of lasting astroglial (but not the neuronal)

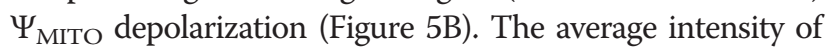
$\Delta \mathrm{F} / \mathrm{F}_{0}$ changes in neurons and astrocytes were also significantly decreased (Figure $5 \mathrm{C}$ ). 


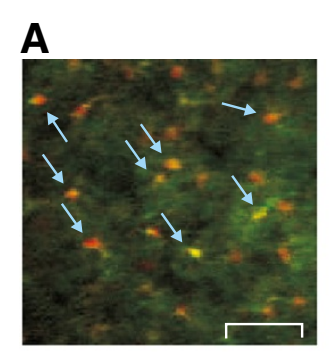

B

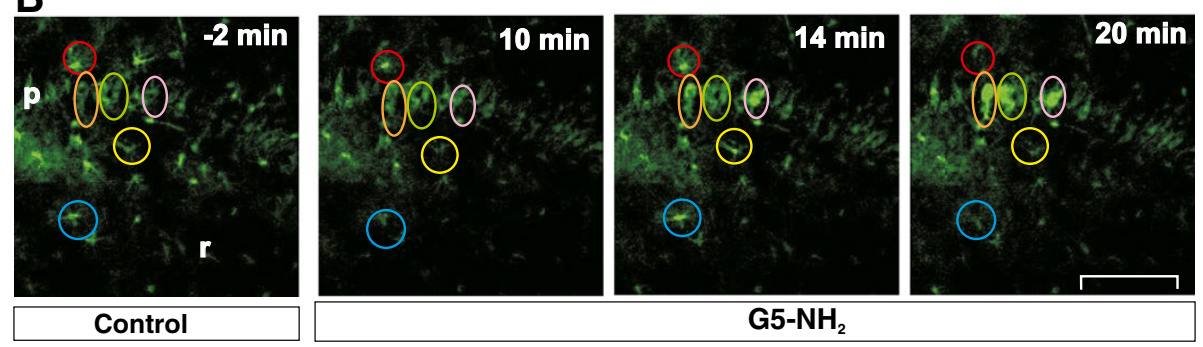

C
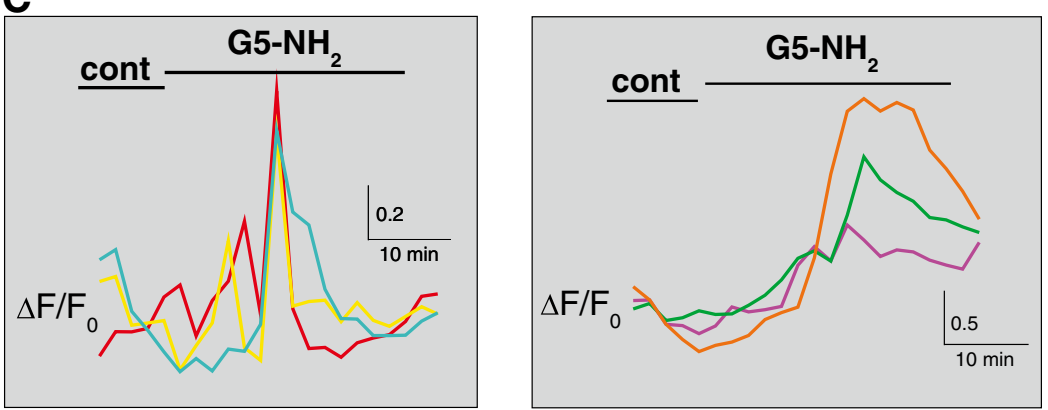

D

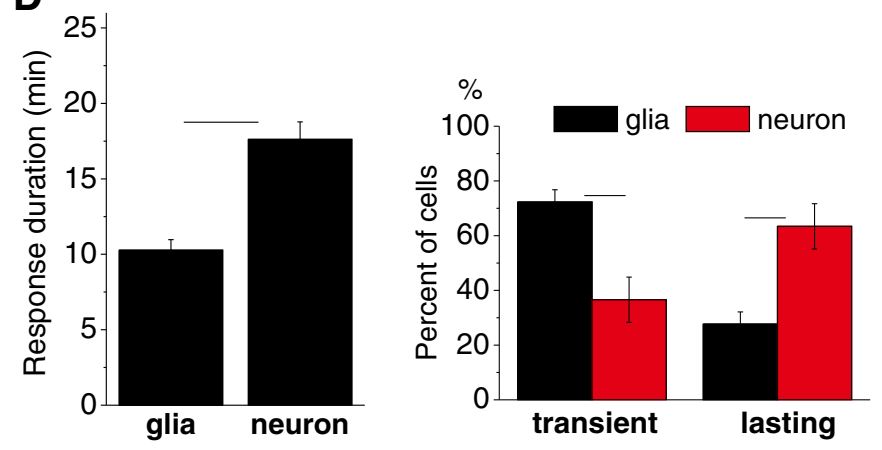

Figure $3 \mathrm{G} 5-\mathrm{NH}_{2}(0.1 \mathrm{mg} / \mathrm{ml}, 30 \mathrm{~min})$ induces distinguishable mitochondrial membrane $\left(\Psi_{\text {МІто }}\right)$ depolarization in astroglial and neuronal cells as monitored with the fluorescent rhodamine-123 indicator. A: Co-localization (yellow cells pointed by blue arrows) of astroglial cells stained with the astroglia-specific marker SR101 (red) with the $\Psi_{\text {MITO }}$ depolarization indicator rhodamine-123 (green).

B: Representative serial images showing $\Psi_{\text {MITO }}$ depolarization in the circled cells in the CA3 stratum pyramidale ( $p$ ) and CA3 stratum radiatum ( $r$ ) areas of the rat hippocampal slice. Scale bar: $50 \mu \mathrm{m}$. C: Fluorescence-time plots of astroglial (Left) and neuronal (Right) cells circled in B.

D: Statistical evaluation of astroglial vs. neuronal effects of $\mathrm{G} 5-\mathrm{NH}_{2}$ on $\Psi_{\text {MITO }}$ depolarization dynamics: $\Psi_{\text {MITO }}$ depolarization duration (Left) and percent of cells showing transient and lasting $\Psi_{\text {MITO }}$ depolarization (Right). Asterisks represent significant differences at $p<0.05$ level.

Neurons and astroglial cells are functionally interconnected within the brain. Increased neuronal activation could led to astroglial $\Psi_{\text {MITO }}$ depolarization [13,14]. If astroglial $\Psi_{\text {MITO }}$ depolarization found in our experiments is only the consequence of the $\mathrm{G} 5-\mathrm{NH}_{2}$-evoked neuronal activation then inhibition of neuronal activity should prevent $\Psi_{\text {MITO }}$ depolarization in astroglia. Therefore the unchanged number of responding glial cells (Figure 5A) indicates that $\mathrm{G} 5-\mathrm{NH}_{2}$ directly evoked mitochondrial depolarization in astroglia, while the decreased duration 


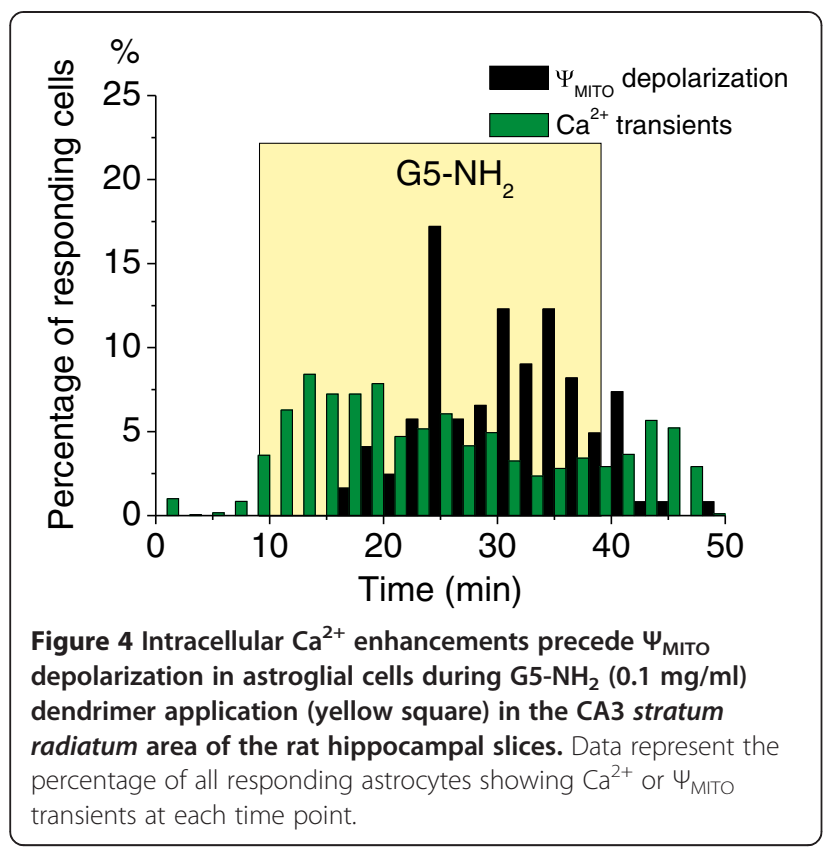

(Figure 5B) and intensity (Figure 5C) in astroglial cells suggests that neuronal activation by $\mathrm{G} 5-\mathrm{NH}_{2}$ intensified the astroglial responses.

\section{Astrocytes are more resistant to PAMAM dendrimer neurotoxicity than neurons}

Lasting $\Psi_{\text {MITO depolarization of neuronal and some }}$ astroglial cells might indicate irreversible disturbances of cellular metabolism [13-15,27]. Predominantly shorter astroglial responses, however, suggest that $\mathrm{G} 5-\mathrm{NH}_{2}$ application might be less harmful to astrocytes probably because astroglial $\Psi_{\text {MITO }}$ can be recovered after several minutes of depolarization [26]. To assess the consequence of $\mathrm{G} 5-\mathrm{NH}_{2}$ induced $\Psi_{\text {MITO }}$ depolarization we measured the viability of astrocytes and neurons by labeling the live cells with calcein after 30 min exposure to $\mathrm{G} 5-\mathrm{NH}_{2}$. The SR101 positive astroglial cells showed robust calcein fluorescence in the stratum radiatum after $30 \mathrm{~min}$ of $\mathrm{G} 5-\mathrm{NH}_{2}$ application indicating the presence of functional, viable astroglial cells [28] (Figure 6A Top, $\mathrm{n}=3$ slices), although viability of astrocytes in the stratum lucidum region may also be compromised. Contrary, in accordance with our previous observations [13], a large proportion of hippocampal pyramidal neurons lost their viability after $30 \mathrm{~min}$ application of $\mathrm{G} 5-\mathrm{NH}_{2}$ despite the survival of astrocytes in the same region (Figure 6 Middle and Bottom). These findings are in accordance with the neuronal activity-dependent lasting $\Psi_{\text {MITO }}$ (c.f. Figure 4) and plasma membrane [7] depolarization. Transient as opposed to lasting $\Psi_{\text {MITO }}$ depolarization in astroglia and neurons, respectively, indicates that the neurotoxicity [7] of $\mathrm{G} 5-\mathrm{NH}_{2}$ may predominantly be restricted to neurons over astroglia.

\section{Conclusion}

G5- $\mathrm{NH}_{2}$ activates both astrocytes and neurons in acute hippocampal slices as reflected by intracellular $\mathrm{Ca}^{2+}$ enhancement and $\Psi_{\text {MITO }}$ depolarization. We showed that the interaction of PAMAM dendrimer with the plasmamembrane evokes $\Psi_{\text {MITO }}$ depolarization most probably via the enhancement of intracellular $\mathrm{Ca}^{2+}$ level. Vast majority of astrocytes shows transient response and remains viable. In contrast, lasting activation of neurons by $\mathrm{G} 5-\mathrm{NH}_{2}$ provokes fatal consequences in accordance with the predominantly irreversible early depolarization of neurons [7]. Due to the connection between elevated
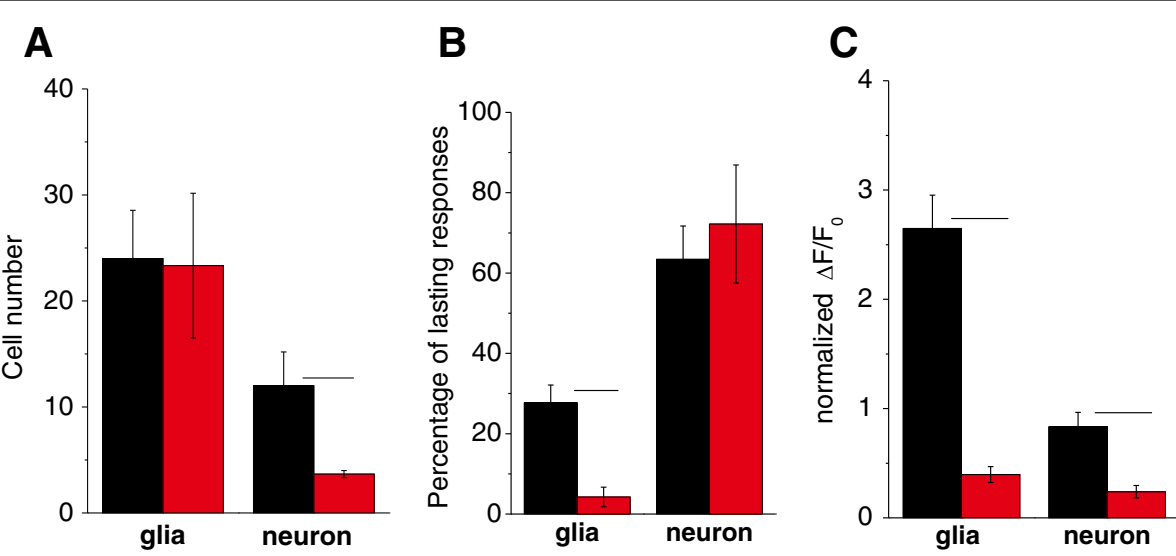

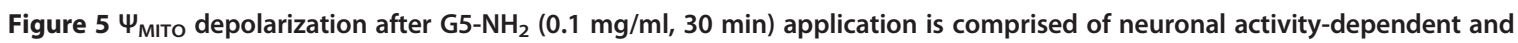

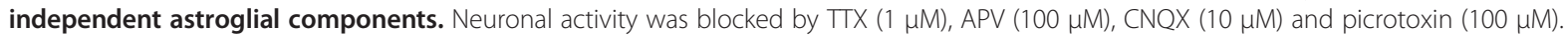
Characteristic $\Psi_{\text {MITO }}$ depolarization parameters, e.g. the number $(\mathbf{A})$, length $(\mathbf{B})$ and normalized fluorescence changes $(\mathbf{C})$ of astroglial cells and neurons are shown. Fluorescence changes $\left(\Delta F / F_{0}\right)$ were normalized to $\Psi_{\text {MITO }}$ depolarization evoked by the mitochondrial inhibitor CCCP $(10 \mu M)$. Asterisks represent significant differences at $p<0.05$ level. 

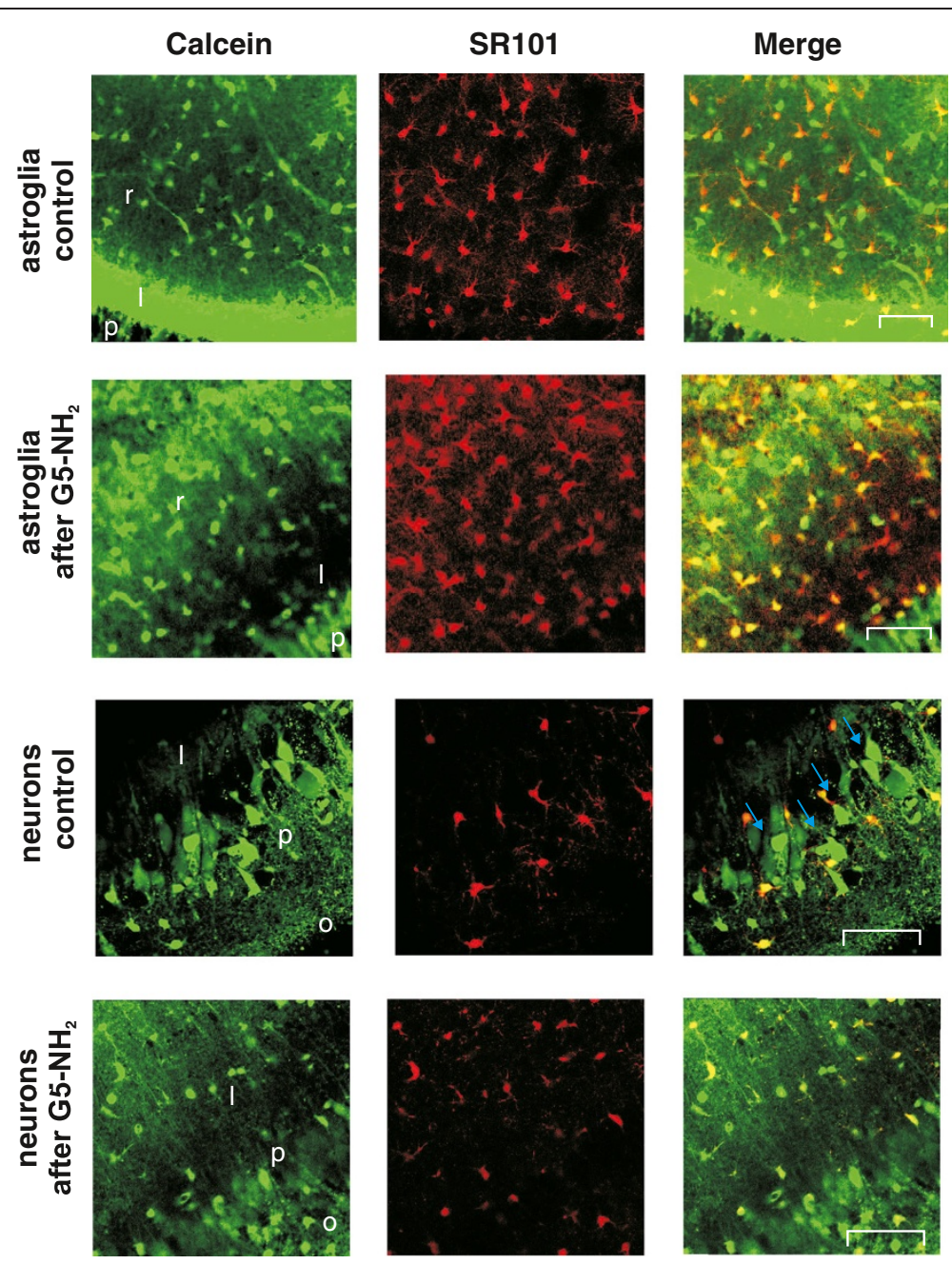

Figure 6 Incubation of the rat hippocampal slice with $0.1 \mathrm{mg} / \mathrm{ml} \mathrm{G5}-\mathrm{NH}_{2}$ for $30 \mathrm{~min}$ differently affects the viability of astroglial cells and neurons. Cells are stained with the fluorescent live-cell specific marker calcein-AM (green) and astroglia specific SR-101 (red). Merged images show viable astroglia (yellow) and viable neurons (green cells pointed by blue arrows). Scale bars: 100 m. O: str. oriens; P: str. pyramidale; L: str. lucidum. Scale bars: $100 \mu \mathrm{m}$.

$\mathrm{Ca}^{2+}$ signal and $\Psi_{\text {MITO }}$ depolarization, as well as formation of reactive oxygen species [11,13,16,27], we can also infer the early disturbance of oxidative metabolism as the primary cause of PAMAM dendrimer evoked neuronal toxicity.

\section{Methods}

\section{Chemicals}

PAMAM dendrimer $\left(\mathrm{G} 5-\mathrm{NH}_{2}\right)$ was purchased from Dendritech Inc. (Dendritech.com, USA). All other chemicals were obtained from Sigma-Aldrich unless otherwise stated.

\section{Slice preparation}

Animal experiments were carried out in accordance with the European Communities Council Directive of 24
November 1986 (86/609/EEC) and the Hungarian Animal Act, 1998 and associated local guidelines. Transverse $400 \mu \mathrm{m}$ thick hippocampal slices of juvenile (1016 days old) male Wistar rats (Toxicoop, Budapest, Hungary) were prepared as described elsewhere [7]. Slices were submerged and perfused at $2 \mathrm{ml} / \mathrm{min}$ by artificial cerebrospinal fluid (ACSF, composition in $\mathrm{mM}$ : $129 \mathrm{NaCl}, 10$ glucose, $3 \mathrm{KCl}, 1.25 \mathrm{NaH}_{2} \mathrm{PO}_{4}, 1.8 \mathrm{MgSO}_{4}$, $2 \mathrm{CaCl}_{2}$ and $\left.21 \mathrm{NaHCO}_{3}\right)$, saturated with carbogen (5\% $\mathrm{CO}_{2}+95 \% \mathrm{O}_{2}$ ), pH 7.4.

\section{Imaging}

In order to monitor changes in intracellular $\mathrm{Ca}^{2+}$, rat brain hippocampal slices were incubated with $5 \mu \mathrm{M}$ Fluo-4 AM in ACSF for one hour at $35^{\circ} \mathrm{C}$ in the dark under humidified carbogen atmosphere after 
preincubation in $2 \%$ pluronic acid containing ACSF for 2 minutes [10]. To allow the cleavage of the AM ester group of Fluo-4, slices were transferred to dye-free ACSF at least 30 minutes before the start of the experiment.

In order to monitor changes in $\Psi_{\text {MITO }}$ rat brain hippocampal slices were loaded with the fluorescent $\Psi_{\text {MITO }}$ indicator rhodamine- $123(15 \mu \mathrm{g} / \mathrm{ml}$ in ACSF $)$ for 20 minutes at $25^{\circ} \mathrm{C}$ [14]. To identify astrocytes slices were loaded with sulforodamine-101 immediately after slicing $\left(1 \mu \mathrm{M}, 20\right.$ minutes, $\left.35^{\circ} \mathrm{C},[29]\right)$ before rhodamine-123 loading.

Dye-loaded slices were placed into the observation chamber and superfused with ACSF and G5- $\mathrm{NH}_{2}$ $(0.1 \mathrm{mg} / \mathrm{ml}$ in ACSF). Change in Fluo- 4 and rhodamine123 fluorescence $\left(\lambda_{\mathrm{ex}}=488 \mathrm{~nm}, \lambda_{\mathrm{em}}=510-530 \mathrm{~nm}\right)$ and SR101 $\left(\lambda_{\text {ex }}=543 \mathrm{~nm}, \lambda_{\mathrm{em}}=570-660 \mathrm{~nm}\right)$ was imaged by a confocal laser scanning microscope (FluoView300, Olympus, Hungary) by 2 min or $10 \mathrm{sec}$ image intervals for rhodamine-123 and Fluo-4 labeling, respectively. Average values of responding astroglial cells per slice showing $\Psi_{\text {MITO }}$ depolarization and $\mathrm{Ca}^{2+}$ enhancements were $24 \pm 5$ and $39 \pm 7$ respectively. Control images were taken for 8 minutes of ACSF perfusion followed by 30 minutes application of $0.1 \mathrm{mg} / \mathrm{ml}$ G5- $\mathrm{NH}_{2}$ and a 10 minute washout period (in Fluo-4 experiments). In $\Psi_{\text {MITO }}$ experiments carbonyl cyanide 3-chlorophenylhydrazone (CCCP, $10 \mu \mathrm{M}$ in $0.1 \%$ DMSO) was applied at the end of the measurement to determine rhodamine-123 intensity corresponding to total $\Psi_{\text {MITO }}$ depolarization.Under control conditions, rhodamine-123 enters mitochondria and, due to self-quenching, the overall fluorescence is low. When the mitochondria depolarize, dye leaves the mitochondria resulting in fluorescence enhancement $[15,29]$.

Astroglial cell viability was measured using CalceinAM fluorescent dye $\left(\lambda_{\text {ex }}=488 \mathrm{~nm}, \lambda_{\mathrm{em}}=510-530\right.$ $\mathrm{nm})$. The intracellular esterase activity could be used as a probe of viability and plasma membrane competence and as an indicator of the cellular functionality [28]. Calcein-AM is a membrane-permeable nonfluorescent molecule that enters intact living cells, then it is cleaved by endogenous esterases to produce the highly fluorescent, membrane impermeable molecule, calcein.

\section{Data evaluation}

Images recorded by the FluoView300 software were processed using the free Image 1.41 image analysis software (http://rsbweb.nih.gov/ij/). Matlab 6.1 was used to evaluate fluorescence changes and the number of responding cells and frequency of fluorescent transients. To avoid differences between slices G5- $\mathrm{NH}_{2}$ evoked changes in fluorescence intensity $\left(\Delta \mathrm{F} / \mathrm{F}_{0}\right)$ were normalized to the average response of the cells to $10 \mu \mathrm{M}$ CCCP, a well known mitochondrial inhibitor applied at the end of the experiments $\left(\triangle \mathrm{F} / \mathrm{F}_{0}\right.$ after CCCP application was $2.2 \pm 0.4$ for astroglial cells and $1.5 \pm 0.16$ for neurons). Data presented are mean \pm S.E.M. Statistical analysis was performed using one-way Anova (OriginLab Co., Northampton, UK) and $\mathrm{p}<0.05$ was considered statistically significant.

\section{Synthesis of fluorescently labeled $\mathrm{G} 5-\mathrm{NH}_{2}$}

Rhodamine Green was covalently bound to $\mathrm{G} 5-\mathrm{NH}_{2}$ by reacting aqueous solution of $\mathrm{G} 5-\mathrm{NH}_{2}(1400 \mu \mathrm{l}, 1.97$ $\mu \mathrm{mol}, 4.05 \mathrm{w} / \mathrm{w} \%)$ with Rhodamine Green carboxylic acid succinimidyl ester hydrochloride mixed isomers (5(6)-CR 110, SE; Molecular Probes, Eugene, OR, USA) (1 mg, $1.97 \mu \mathrm{mol}$ ) dissolved in $\mathrm{N}, \mathrm{N}$-dimethylformamide $(100 \mu \mathrm{l})$ in $0.1 \mathrm{M} \mathrm{NaHCO}_{3}$ buffer (1.4 ml, pH 8.5) at room temperature for $2 \mathrm{~h}$ in dark. The unreacted dye was removed from the solution by ultrafiltration (3 $000 \mathrm{MWCO}$ ) in Amicon Ultracel - 3K centrifugal filter units. Amine reactive form of the Rhodamine Green dye was coupled covalently to the PAMAM dendrimer forming amide bonds. The unreacted dye was then removed by ultrafiltration and the conjugate containing no dye was used throughout the experiments. The conjugate is hydrolitically stable under physiological conditions therefore the localization of the dendrimer can be interpreted by the detected fluorescence.

\section{Abbreviations}

G5- $\mathrm{NH}_{2}$ : PAMAM generation 5 dendrimer; $\Psi_{\text {MITO}}$ : mitochondrial membrane potential; SR101: Sulforhodamine-101; TTX: Tetrodotoxin; APV: DL-2-Amino-5phosphonopentanoic acid; CNQX: 6-cyano-7-nitroquinoxaline-2,3-dion; CCCP: Carbonyl cyanide 3-chlorophenylhydrazone.

\section{Competing interests}

The authors declare that they have no competing interests.

\section{Authors' contributions}

Conceived and designed the experiments: GNy, LH, JK. Performed the experiments: GNy, IP. Analyzed the data: GNy. Synthetized and filtrated the fluorescently labeled dendrimer: IJ. and JV. Wrote the paper: GNy, LH, JK. All authors read and approved the final manuscript.

\section{Acknowledgements}

This work was supported by grants ERA-Chemistry OTKA 102166, TECH-09-Al2009-0117 NKFP NANOSEN9 and KMR_12-1-2012-0112 TRANSRAT. G.Ny. thanks Erzsébet Fekete Kútiné for her assistance with brain slice preparation.

\section{Author details}

'Department of Functional Pharmacology, Institute of Molecular Pharmacology, Research Centre for Natural Sciences, Hungarian Academy of Science, Budapest, Hungary. ${ }^{2}$ Department of Biochemical Pharmacology, Laboratory of Chemical Pharmacology, Research Centre for Natural Sciences, Hungarian Academy of Science, Budapest, Hungary.

Received: 7 December 2012 Accepted: 8 March 2013

Published: 4 April 2013 


\section{References}

1. Huang RQ, Qu YH, Ke WL, Zhu JH, Pei YY, Jiang C: Efficient gene delivery targeted to the brain using a transferrin-conjugated polyethyleneglycolmodified polyamidoamine dendrimer. FASEB J 2007, 21:1117-1125.

2. Yang $\mathrm{H}$ : Nanoparticle-mediated brain-specific drug delivery, imaging, and diagnosis. Pharm Res 2010, 27:1759-1771.

3. Gupta U, Agashe HB, Asthana A, Jain NK: A review of in vitro-in vivo investigations on dendrimers: the novel nanoscopic drug carriers. Nanomedicine 2006, 2:66-73.

4. Hong S, Leroueil PR, Janus EK, Peters JL, Kober MM, Islam MT, Orr BG, Baker JR Jr, Banaszak Holl MM: Interaction of polycationic polymers with supported lipid bilayers and cells: nanoscale hole formation and enhanced membrane permeability. Bioconjug Chem 2006, 17:728-734

5. Jain K, Kesharwani P, Gupta U, Jain NK: Dendrimer toxicity: let's meet the challenge. Int J Pharm 2010, 394:122-142.

6. Li C, Liu H, Sun Y, Wang H, Guo F, Rao S, Deng J, Zhang Y, Miao Y, Guo C, et al: PAMAM nanoparticles promote acute lung injury by inducing autophagic cell death through the Akt-TSC2-mTOR signaling pathway. J Mol Cell Biol 2009, 1:37-45.

7. Nyitrai G, Kékesi O, Pál I, Keglevich P, Csiki Z, Fügedi P, Simon A, Fitos I, Nemeth K, Visy J, et al: Assessing toxicity of polyamidoamine dendrimers by neuronal signaling functions. Nanotoxicology 2012, 6:576-586.

8. Haydon PG, Carmignoto G: Astrocyte control of synaptic transmission and neurovascular coupling. Physiol Rev 2006, 86:1009-1031.

9. Perea G, Araque A: GLIA modulates synaptic transmission. Brain Res Rev 2010, 63:93-102

10. Molnár T, Dobolyi A, Nyitrai G, Barabás P, Héja L, Emri Z, Palkovits M, Kardos $\mathrm{J}$ : Calcium signals in the nucleus accumbens: activation of astrocytes by ATP and succinate. BMC Neurosci 2011, 12:96

11. Cabezas R, El-Bacha RS, Gonzalez J, Barreto GE: Mitochondrial functions in astrocytes: neuroprotective implications from oxidative damage by rotenone. Neurosci Res 2012, 74:80-90.

12. Hamby ME, Sofroniew MV: Reactive astrocytes as therapeutic targets for CNS disorders. Neurotherapeutics 2010, 7:494-506.

13. Abramov AY, Duchen MR: Impaired mitochondrial bioenergetics determines glutamate-induced delayed calcium deregulation in neurons. Biochim Biophys Acta 1800, 2010:297-304.

14. Kovács R, Kardos J, Heinemann U, Kann O: Mitochondrial calcium ion and membrane potential transients follow the pattern of epileptiform discharges in hippocampal slice cultures. J Neurosci 2005, 25:4260-4269.

15. Kann O, Kovacs R: Mitochondria and neuronal activity. Am J Physiol Cell Physiol 2007, 292:C641-657

16. Szárics E, Riedl Z, Nyikos L, Hajós G, Kardos J: Interaction of novel condensed triazine derivatives with central and peripheral type benzodiazepine receptors: synthesis, in vitro pharmacology and modelling. Eur J Med Chem 2006, 41:445-456.

17. Kerr JN, Greenberg D, Helmchen F: Imaging input and output of neocortical networks in vivo. Proc Natl Acad Sci USA 2005, 102:14063-14068.

18. Rózsa B, Zelles T, Vizi ES, Lendvai B: Distance-dependent scaling of calcium transients evoked by backpropagating spikes and synaptic activity in dendrites of hippocampal interneurons. J Neurosci 2004, 24:661-670.

19. Honsek SD, Walz C, Kafitz KW, Rose CR: Astrocyte calcium signals at Schaffer collateral to CA1 pyramidal cell synapses correlate with the number of activated synapses but not with synaptic strength. Hippocampus 2012, 22:29-42.

20. Perea G, Araque A: Properties of synaptically evoked astrocyte calcium signal reveal synaptic information processing by astrocytes. J Neurosci 2005, 25:2192-2203.

21. Kelly CV, Liroff MG, Triplett LD, Leroueil PR, Mullen DG, Wallace JM, Meshinchi S, Baker JR, Orr BG, Banaszak Holl MM: Stoichiometry and structure of poly(amidoamine) dendrimer-lipid complexes. ACS Nano 2009, 3:1886-1896

22. Lee H, Larson RG: Coarse-grained molecular dynamics studies of the concentration and size dependence of fifth- and seventh-generation PAMAM dendrimers on pore formation in DMPC bilayer. J Phys Chem $B$ 2008, 112:7778-7784.

23. Albertazzi L, Serresi M, Albanese A, Beltram F: Dendrimer internalization and intracellular trafficking in living cells. Mol Pharm 2010, 7:680-688.

24. Molnár T, Barabas P, Héja L, Fekete EK, Lasztóczi B, Szabó P, Nyitrai G, Simon-Trompler E, Hajós F, Palkovits M, Kardos J: gamma-Hydroxybutyrate binds to the synaptic site recognizing succinate monocarboxylate: a new hypothesis on astrocyte-neuron interaction via the protonation of succinate. J Neurosci Res 2008, 86:1566-1576.

25. Lee JH, Cha KE, Kim MS, Hong HW, Chung DJ, Ryu G, Myung H: Nanosized polyamidoamine (PAMAM) dendrimer-induced apoptosis mediated by mitochondrial dysfunction. Toxicol Lett 2009, 190:202-207.

26. Reichert SA, Kim-Han JS, Dugan LL: The mitochondrial permeability transition pore and nitric oxide synthase mediate early mitochondrial depolarization in astrocytes during oxygen-glucose deprivation. J Neurosci 2001, 21:6608-6616.

27. Kovács R, Schuchmann S, Gabriel S, Kann O, Kardos J, Heinemann U: Free radical-mediated cell damage after experimental status epilepticus in hippocampal slice cultures. J Neurophysio/ 2002, 88:2909-2918.

28. Palma PF, Baggio GL, Spada C, Silva RD, Ferreira SI, Treitinger A: Evaluation of annexin $\mathrm{V}$ and Calcein-AM as markers of mononuclear cell apoptosis during human immunodeficiency virus infection. Braz J Infect Dis 2008, 12:108-114.

29. Nicholls DG: Simultaneous monitoring of ionophore- and inhibitormediated plasma and mitochondrial membrane potential changes in cultured neurons. J Biol Chem 2006, 281:14864-14874

doi:10.1186/1477-3155-11-9

Cite this article as: Nyitrai et al:: Polyamidoamine dendrimer impairs mitochondrial oxidation in brain tissue. Journal of Nanobiotechnology 2013 11:9.

\section{Submit your next manuscript to BioMed Central and take full advantage of:}

- Convenient online submission

- Thorough peer review

- No space constraints or color figure charges

- Immediate publication on acceptance

- Inclusion in PubMed, CAS, Scopus and Google Scholar

- Research which is freely available for redistribution 